Reprod. Nutr. Dévelop., 1988, 28 (2 A), 319-334.

\title{
Estramustine phosphate inhibits germinal vesicle breakdown and induces depolymerization of microtubules in mouse oocyte
}

\author{
Hélène RIME ( ${ }^{1}$ ), Catherine JESSUS, R. OZON \\ Laboratoire de Physiologie de la Reproduction, Groupe Stéroïdes, \\ UA-CNRS 555 , \\ Université Pierre et Marie Curie, 4, place Jussieu, 75252 Paris Cedex 05, France.
}

Summary. The first meiotic cell division (meiotic maturation) of the dictyate stage of mouse oocytes, removed from the follicle, resumes spontaneously in vitro. This study indicates that estramustine phosphate reversibly blocks meiotic maturation by inhibiting germinal vesicle breakdown. Oocyte cryostat sections were stained with anti-tubulin and two antibodies (anti-MAP1 : JA2 and 5051) which decorated the metaphase spindle during meiotic maturation. It was found that (1) estramustine phosphate depolymerized microtubules in ovo and dispersed non-tubulin antigens associated with microtubules of the metaphase spindle at various stages of maturation, and (2) estramustine phosphate decreased the ability of taxol to induce cytoplasmic asters. These results suggest that germinal vesicle breakdown and microtubule polymerization may be linked.

\section{Introduction.}

The small number of prophase microtubules present in mouse oocyte, which contains no centriole (Szöllösi et al., 1972b), are replaced during first meiotic cell division or meiotic maturation by a large number of spindle microtubules. Microtubule nucleation capacity increases at the nucleoplasm-cytoplasm interface at the onset of nuclear envelope breakdown (Calarco et al., 1972 ; Szöllösi et al., $1972 a$, b). At the same time, the critical level of tubulin polymerization decreases since taxol can then induce the formation of numerous spindle-like structures (Rime et al., 1987). These observations indicate that new microtubule-organizing centers (MTOCs) are generated during the breakdown of the nuclear envelope. The role of microtubule-associated proteins (MAPs) in this process is poorly understood. It has been shown however that antigens stained by anti-MAP antibodies are present in the mitotic spindle (Izant et al., 1982 ; Bloom et al., 1984 ; Wiche et al., 1984 ; Bonifacino et al. (1985). We have shown recently that

(1) Correspondence and reprints : Hélène RIME. 
the first and second meiotic metaphase spindles in mouse oocyte can be decorated with a monoclonal antibody raised against MAP1 from rat brain (Rime et al., 1987). The immunofluorescence studies of Calarco-Gillam et al. (1983), Maro et al. (1985) and Schatten et al. (1986) have shown that 5051 antibody, a polyclonal antibody taken from a scleroderma patient and recognizing MTOC in somatic cells (Calarco-Gillam et al., 1983 ; Brinkley, 1985), also marks the poles of barrel-shaped metaphase II of mouse oocyte. Although the mouse oocyte antigens recognized by these antibodies were not biochemically characterized, they ran be considered to be spindle-associated antigens, according to cytological criteria. These antibodies have been used as a tool to analyse the cellular distribution of meiotic microtubule-associated non-tubulin proteins during germinal vesicle breakdown (GVBD) in mouse oocyte.

Estramustine phosphate, a cytotoxic anti-mitotic compound, has been shown recently to inhibit microtubule assembly in vitro by interacting with MAPs (Hartley-Asp, 1984 ; Kanje et al., 1985; Wallin et al., 1985). Estramustine phosphate also produces microtubule disassembly in vivo in different cell lines (Stearns and Tew, 1985). Estramustine may act in vivo by binding to MAPs in the whole cell. It was therefore of interest to know if estramustine phosphate could interact directly or indirectly with non-tubulin proteins associated with metaphase microtubules in mouse oocyte.

The present study shows that estramustine phosphate reversibly destabilized mouse oocyte metaphase microtubules and disorganized the immunofluorescence staining obtained with both the 5051 and the JA2 antibodies. Estramustine phosphate also inhibited the breakdown of the nuclear envelope and the formation of spindle microtubules.

\section{Materials and methods.}

Chemicals. - Estramustine phosphate, estradiol-3-(N,N-bis-(2 chloro-ethyl) carbamate) $17 \beta$-phosphate, was the gift of $\mathrm{Dr}$ Hartley-Asp, AB Leo Research Laboratories, Helsingborg, Sweden. Taxol was the gift of Dr M. Süffness of the NIH, Bethesda, MD, USA.

Oocyte collection and culture. - Follicular oocytes were obtained from the ovaries of 8 to 14-week old Swiss albino mice (Ifacredo, France). The mice were killed by cervical dislocation and their ovaries removed and placed in a Petri dish containing M2 culture medium (Fulton and Whittingham, 1978). The antral follicles were carefully dissected and the oocytes liberated by puncturing the follicle with a needle. 20 to 40 oocytes, obtained in this way from each mouse, were cultured in $\mathrm{M} 2$ under paraffin oil equilibrated with the medium at $37^{\circ} \mathrm{C}$.

Antibodies. - Mouse monoclonal antibody against $\beta$-tubulin of chick brain was obtained from Amersham (N.357). Mouse monoclonal antibody against rat brain MAP1 (JA2) was the gift of Dr M. De Brabander, Janssen Pharmaceutica Research Laboratories, Beerse, Belgium (De Mey et al., 1984 ; De Brabander et al., 1985). Antibodies against pericentriolar material (microtubule-organizing center or MTOC) and the centriole cylinder were contained in the serum of a 
human patient with linear scleroderma (Calarco-Gillam et al., 1983). This antibody was the gift of Dr Calarco-Gillam, University of California, Medical Center, San Francisco, USA. An antiserum specific to BHK matrix proteins was a gift from by Dr Simard, Institut du Cancer de Montréal, Canada (Dagenais et al., 1984).

For indirect immunofluorescence, the second antibody was directed against the species of the first antibody : anti-mouse Ig fluorescein-labeled antibody from sheep (Amersham, N.1031) and anti-mouse lg Texas red-labeled antibody from sheep (Amersham, N.2031) for the anti-tubulin monoclonal antibody, anti-mouse IgM fluorescein-labeled antibody from rats (Biosys, N.5059) for the JA2 monoclonal antibody and anti-human $\operatorname{lgG}$.AM fluorescein-labeled antibody from goats (Institut Pasteur Production, N.74511) for the anti-MTOC (5051) antibody.

Immunocytochemical procedures. - The mouse oocytes, fixed in acetic $(0.5 \%)$ ethanol $\left(70^{\circ}\right)$ for $30 \mathrm{~min}$ at room temperature, were progressively hydrated and washed in PBS buffer (137 mM NaCl, $2.7 \mathrm{mM} \mathrm{KCl}, 0.5 \mathrm{mM} \mathrm{MgCl}\left(6 \mathrm{H}_{2} \mathrm{O}\right)$, $3.2 \mathrm{mM} \mathrm{Na} \mathrm{HPO}_{4}\left(12 \mathrm{H}_{2} \mathrm{O}\right), 1.5 \mathrm{mM} \mathrm{KHPO}_{4}, 0.68 \mathrm{mM} \mathrm{CaCl}, \mathrm{pH}$ 7.3) before being embedded in gelatin $(20 \%$ in PBS buffer) and cooled in isopentane $\left(-130^{\circ} \mathrm{C}\right)$.

For tubulin or lamin staining, cryostat sections (Frigocut 2700, Reichert-Jung) $(7 \mu \mathrm{m})$ were hydrated and permeabilized $30 \mathrm{~min}$ in PBS buffer containing Saponin $(0.03 \%)$ and then incubated for $15 \mathrm{~min}$ in PBS buffer containing Saponin $(0.03 \%)$ and bovine serum albumin (BSA) (2\%). The sections were then incubated with the anti-tubulin or anti-lamin antibodies, diluted in PBS bufferSaponin $(0.03 \%)$ BSA $(2 \%)$, for $2 \mathrm{~h}$ at room temperature (dilution $1 / 300$ for anti-tubulin antibody and $1 / 100$ for anti-lamin antibody). After incubation with the antibody, the sections were washed in PBS buffer-Saponin $(0.03 \%)$ and incubated for $1 \mathrm{~h}$ in the dark at room temperature with the fluorescein-labeled anti-mouse Ig antibody (dilution $1 / 40$ ) or with the fluorescein-labeled anti-rabbit IgG antibody (dilution $1 / 800$ ) recognizing, respectively, the anti-tubulin and the anti-lamin antibodies. The sections were then washed in PBS buffer-Saponin $(0.03 \%)$ and incubated for $10 \mathrm{sec}$ with Hoechst dye 33258 (Calbiochem) $(2.5 \mu \mathrm{g} /$ $\mathrm{ml}$ in PBS) at room temperature to visualize the chromosomes. The sections were washed in PBS and mounted in glycerol (50\% in PBS buffer).

The same procedure was used with JA2 antibody but the PBS buffer was replaced by $10 \mathrm{mM}$ Tris, $100 \mathrm{mM} \mathrm{NaCl}, \mathrm{pH} 7.6$, because staining with JA2 antibody is blocked by phosphate (De Brabander, personal communication). The sections were incubated for $1 \mathrm{~h} 30$ with JA2 antibody (dilution $1 / 250$ ) at $37{ }^{\circ} \mathrm{C}$ and for $1 \mathrm{~h}$ in the dark at room temperature with the fluorescein-labeled anti-mouse $\lg \mathrm{M}$ antibody (dilution 1/100).

The same procedure was used for double indirect immunofluorescence, i.e. for anti-tubulin and anti-MTOC (5051) antibodies. After incubation with the first (anti-tubulin) and the second antibody (Texas red-labeled anti-mouse Ig antibody) (dilution 1/300), the sections were washed in PBS buffer-Saponin $(0.03 \%$ ), and then incubated with anti-MTOC antibody (5051) diluted in PBS buffer-Saponin $(0.03 \%)$ BSA $(2 \%)$ (dilution $1 / 100)$ for $1 \mathrm{~h}$ in the dark at room temperature. These sections were then washed in PBS buffer-Saponin $(0.03 \%)$ and incubated in the dark for $1 \mathrm{~h}$ at room temperature with the fluorescein-labeled anti-human 
IgG.AM antibody (dilution 1/100), then washed in PBS buffer and mounted as described previously.

In each experiment, the control sections were only incubated with the second antibody. Under these conditions no fluorescence was observed. The specificity of anti- $\beta$ tubulin antibody was ascertained by absorption with an excess $(\times 20)$ of purified tubulin isolated from rat brain, as described by Shelanski et al. (1973).

Observations were made in light epifluorescence $(\lambda: 560 \mathrm{~nm}, 490 \mathrm{~nm}$ and $380 \mathrm{~nm} /$ with a Leitz Dialux 20 microscope. Micrographs were taken using llford HP5 film exposed at 400 ASA and developed in Microphen (llford).

Oocyte treatment.

With estramustine phosphate. - A stock solution of $15 \mathrm{mM}$ estramustine phosphate (gift of Dr Hartley-Asp, Sweden) in absolute ethanol was used in these experiments. The solution was diluted in $\mathrm{M} 2$ medium at various final concentrations between 20 and $50 \mu \mathrm{M}$, and the oocytes were incubated in this medium for various times before fixation. The control experiments were realized by incubating the oocytes in $\mathrm{M} 2$ medium containing the same concentrations of absolute ethanol alone. The nitrogen mustard moiety is known to not mimic estramustine effects (Hartley-Asp and Gunnarsson, 1982).

With taxol. - A stock solution of $10 \mathrm{mM}$ taxol (gift of Dr M. Süffness, Bethesda, MD, USA) in dimethylsulfoxide was used in these experiments. The solution was diluted in $\mathrm{M} 2$ medium at a final concentration of $10 \mu \mathrm{M}$ and the oocytes were incubated in this medium for various times before fixation. The

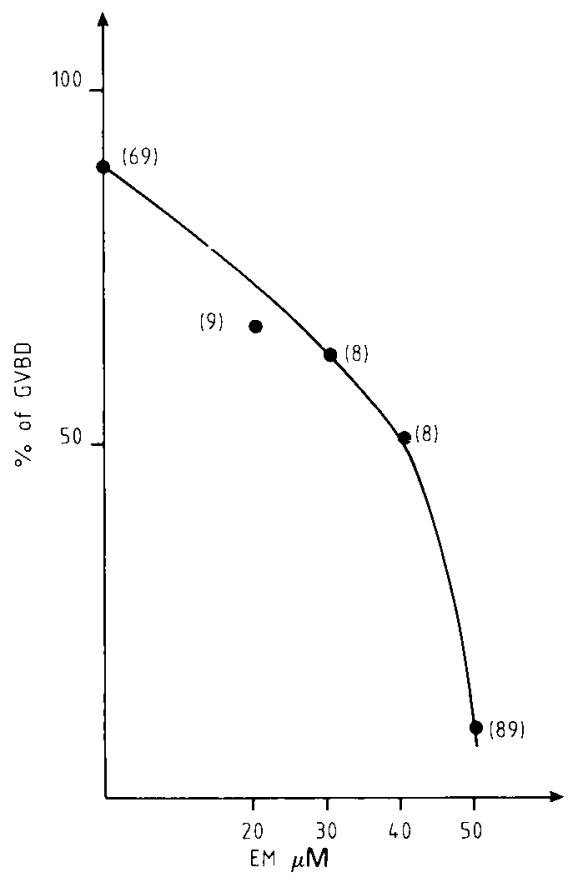

FIG. 1. - Inhibition of germinal vesicle breakdown by estramustine phosphate; dose-reponse curve. Numbers in brackets indicate the number of oocytes analyzed for each concentration of estramustine phosphate. 
control experiments were realized by incubating the oocytes in the $\mathrm{M} 2$ medium containing the same concentrations of dimethylsulfoxide alone.

\section{Results.}

\section{Inhibition of mouse oocyte meiotic maturation by estramustine phosphate}

Oocytes liberated from their follicle spontaneously resume meiosis in vitro (Donahue, 1968). Germinal vesicle breakdown (GVBD) occurred in $89 \%$ of the oocytes removed from the follicle and cultured for $4 \mathrm{~h}$, as judged by examination under the light microscope (fig. 1). Less than $10 \%$ of the oocytes cultured for $4 \mathrm{~h}$ in the incubation medium containing $50 \mu \mathrm{M}$ of estramustine phosphate underwent GVBD (fig. 1). The inhibition of GVBD was dose-dependent, with an ED 50 of $45 \mu \mathrm{M}$. As shown in figure 2, the nuclear lamina, a protein network limiting the nucleoplasmic surface of the nuclear membrane (Gerace et al., 1984), was fragmented at the time of GVBD. It was unchanged after estramustine phosphate action, indicating that the lamina did not depolymerize in the presence of the drug. This observation suggests that estramustine is a potent inhibitor of the first meiotic cell division of mouse oocyte.

The reversibility of estramustine phosphate action was tested by culturing the oocytes for $4 \mathrm{~h}$ in the presence of the drug (50 $\mu \mathrm{M})$ immediately after their release from the follicle. The estramustine phosphate was then washed out and the oocytes placed in the control medium. GVBD occurred $4 \mathrm{~h}$ later and was followed by the extrusion of the first polar body. The inhibition of GVBD by estramustine phosphate was therefore reversible in these experimental conditions. At the concentrations tested, estramustine phosphate inhibition depended on the combined effects of the hydrophobic steroid and the hydrophilic mustard moieties since neither the steroid nor the nitrogen mustard alone inhibit maturation (Hartley-Asp and Gunnarsson, 1982).

\section{Effects of estramustine phosphate on microtubules and microtubule-associated protein during meiotic maturation}

We analysed estramustine phosphate in vivo effect on the cellular distribution of microtubules and of an antigen recognized by an antibody raised against a microtubule-associated protein (MAP1), as well as on the localization of microtubule-organizing centers (MTOCs). Three antibodies were used in this immunofluorescence study on cryostat sections. The first antibody was a monoclonal antibody against MAP1 (antibody JA2, the gift of $\mathrm{Dr} M$. De Brabander) (De Mey et al., 1984 ; De Brabander et al., 1985). The second antibody was a polyclonal autoantibody from a scleroderma patient and recognizes MTOC in somatic cells (Calarco-Gillam et al., 1983) and mouse oocytes (Maro et al., 1985). The third antibody, anti-tubulin antibody from Amersham, was a monoclonal antibody against $\beta$-tubulin.

1) Prophase oocytes. - The oocytes were stained by double indirect immunofluorescence immediately after removal from the follicles. Anti-tubulin antibody produced a light background staining of the whole cytoplasm together 

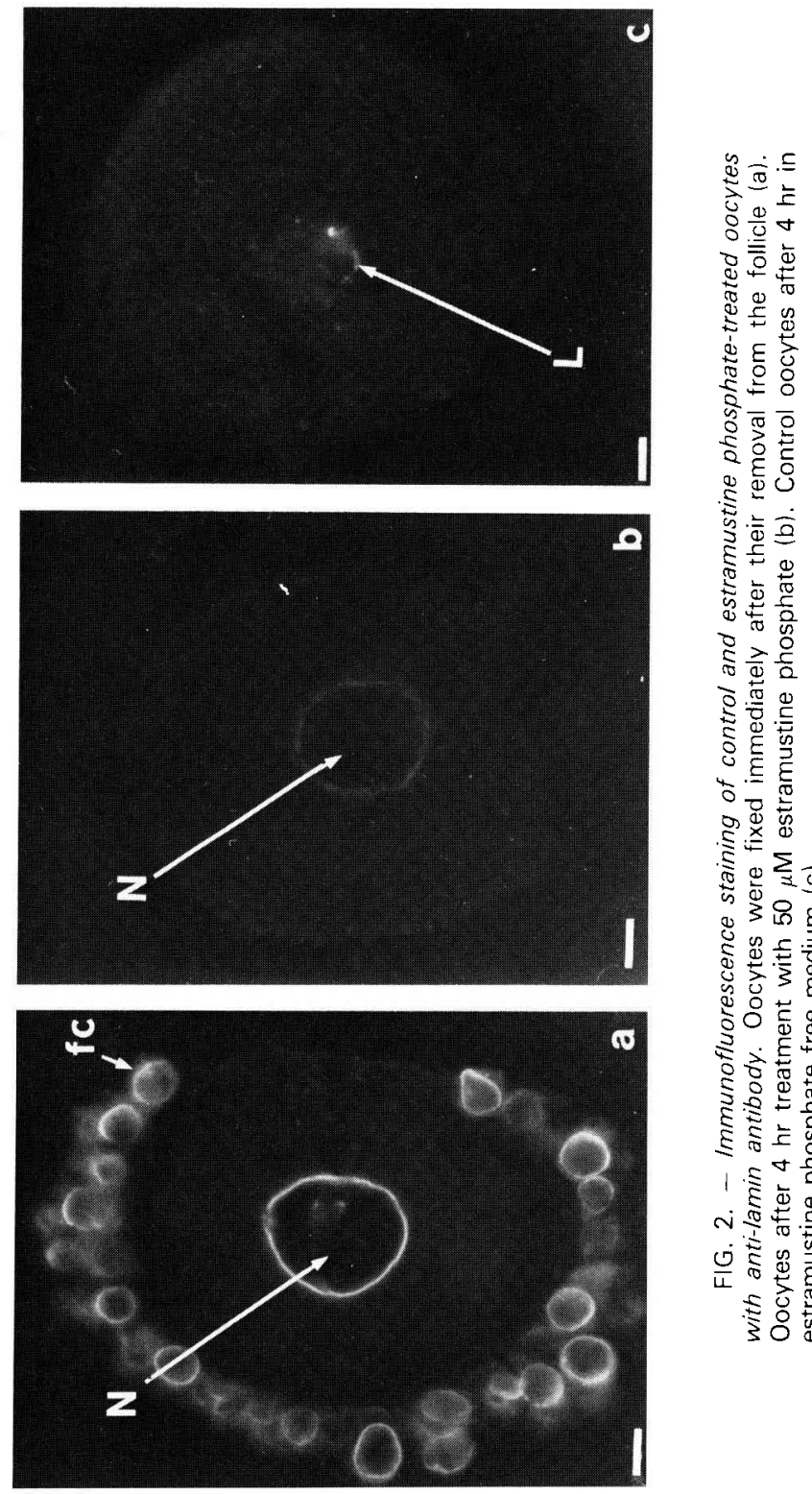

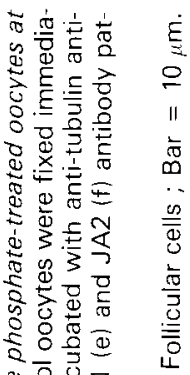

के

空䜤

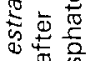

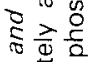

훙

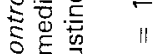

ठํ

$4 \frac{2}{0}$

ธั

O용

S.

施

क 3 员

造事运

牙专要

今ั0

के

今.

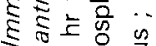

$1 \leqslant \sigma \frac{0}{0}$

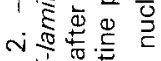

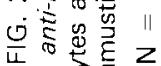

施莺

¿을

证

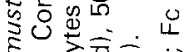

हो 站的

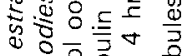

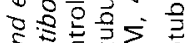

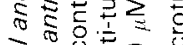

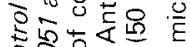

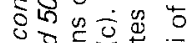

U.

on

พิ้

空

a

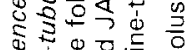

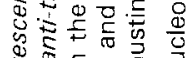

का

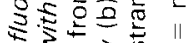

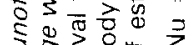

ร

हूँ

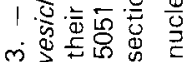

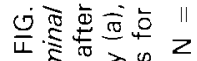

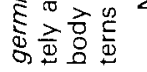


with discrete areas of higher fluorescence near the cytoplasmic surface of the nuclear envelope (fig. 3a). 5051 antibody also decorated this region of the same section (fig. 3b). No fluorescence was seen inside the nucleus. The immunofluorescence pattern of JA2 antibody was strikingly different in oocytes fixed at the GVBD stage, since JA2 antibody decorated only a trabecular structure in addition to the nucleolus inside the germinal vesicle (fig. $3 \mathrm{c}$ ); no fluorescence was seen associated with the perinuclear microtubules.

The germinal vesicle did not break down in oocytes removed from the follicle and cultured for $4 \mathrm{~h}$ in the presence of $50 \mu \mathrm{M}$ estramustine phosphate. Cryostat sections of these oocytes stained with either anti-tubulin or 5051 antibody showed no fluorescence around the germinal vesicle, only a light background staining of the whole cytoplasm (figs. 3d, e). This indicates that both antigens were dispersed in the cytoplasm after estramustine phosphate treatment. In contrast, the JA2 antibody immunofluorescence pattern was unchanged (fig. $3 f$ ).

2) Germinal vesicle breakdown. - Numerous microtubules were stained with anti-tubulin antibody where the nucleus had broken down in oocytes in which GVBD was complete, as judged by light microscopy (after about $4 \mathrm{~h}$ in culture) (fig. 4a). Condensed chromosomes were located inside the area where microtubules were seen. On the same section, the 5051 antibody also decorated the same region (fig. 4b). JA2 antibody also stained this region of a different oocyte section (fig. 4c). The immunofluorescence staining patterns of the antitubulin, 5051 (not shown) and JA2 antibodies totally dissapeared (figs. 4d, e) in oocytes treated with $50 \mu \mathrm{M}$ of estramustine phosphate for $15 \mathrm{~min}$ at the time of GVBD. Under these conditions, the background staining of the cytoplasm by all three antibodies slightly increased.

3) Metaphase oocytes. - The metaphase I spindle ( 9 to $10 \mathrm{~h}$ of culture) and metaphase II spindle (10 to $15 \mathrm{~h}$ of culture) were the only structures decorated by anti-tubulin and 5051 antibodies (figs. 5a, b); they were associated with condensed chromosomes (fig. 5c). 5051 antibody decorated the whole metaphase spindle on cryostat sections of in vitro-matured oocytes, as reported earlier for JA2 antibody (Rime et al., 1987).

Estramustine phosphate (in standard conditions : $15 \mathrm{~min}, 50 \mu \mathrm{M}$ ) abolished the staining patterns of anti-tubulin and 5051 antibodies of metaphase $I$ and metaphase II spindles. But small foci of microtubules could be seen in some cases (figs. 5d, e). The chromosomes remained condensed and aligned in the metaphase plane (fig. $5 f$ ).

FIG. 4. - Immunofluorescence labelling of control and estramustine phosphate-treated oocytes at the time of GVBD with anti-tubulin, 5051 and JA2 antibodies. Control oocytes were fixed at the time of GVBD, as judged by light microscopy ( $4 \mathrm{hr}$ of culture). Sections of control oocytes incubated with anti-tubulin (a), 5051 (b) and JA2 (c) antibodies. Anti-tubulin (d), and JA2 (e) antibody patterns for sections of estramustine phosphate-treated oocytes $(50 \mu \mathrm{M}, 15 \mathrm{~min})$ at GVBD as judged by light microscopy. Anti-tubulin antibody pattern (f) of oocyte treated $15 \mathrm{~min}$ with estramustine phosphate at the time of GVBD, and then incubated $2 \mathrm{hr}$ without the drug : a metaphase I spindle is formed.

$\mathrm{m}=$ microtubules; $\mathrm{Bar}=10 \mu \mathrm{m}$. 

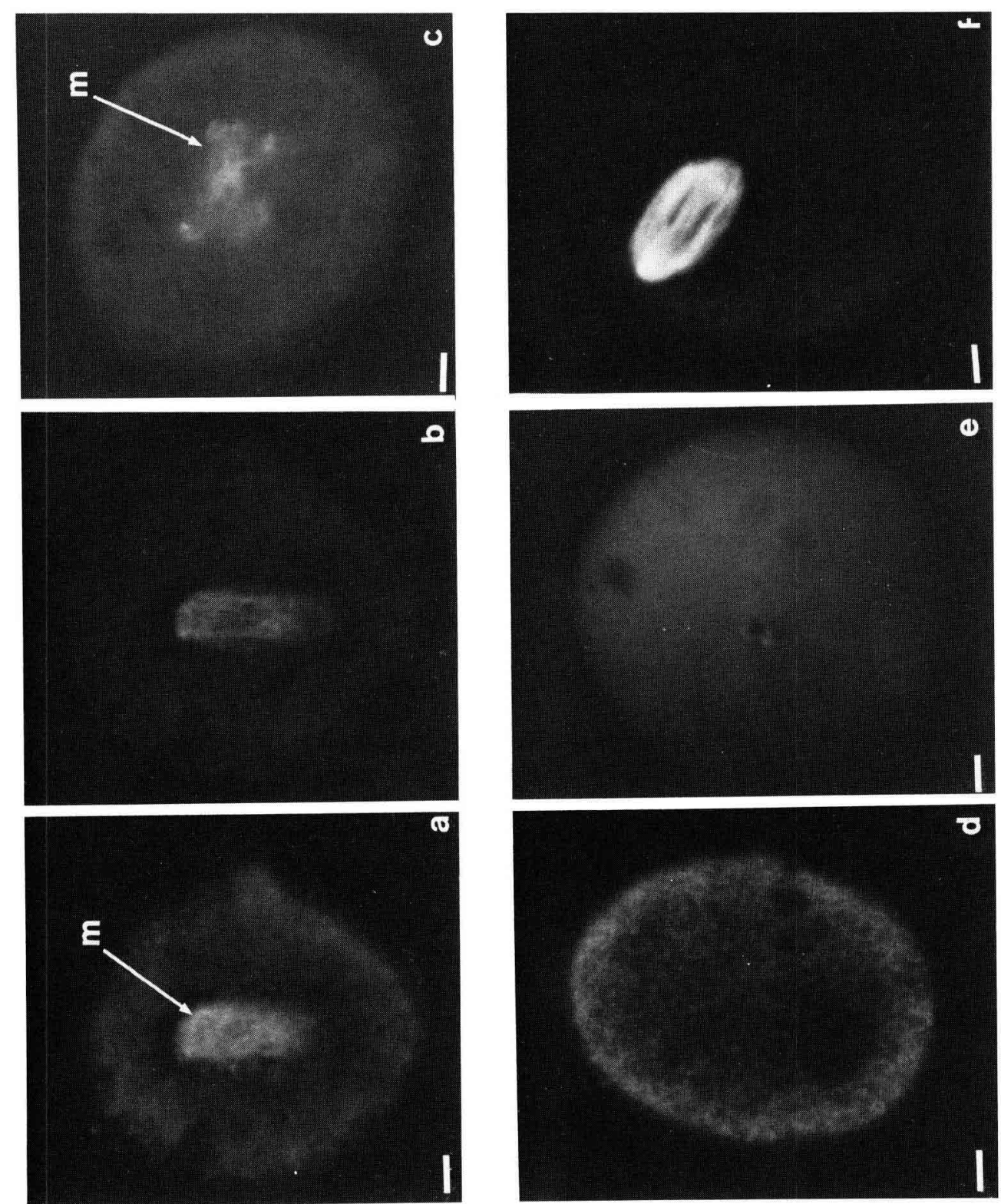
The reversibility of estramustine phosphate action was tested by incubating oocytes at GVBD ( $4 \mathrm{~h}$ of culture) for $15 \mathrm{~min}$ in the presence of $50 \mu \mathrm{M}$ of estramustine phosphate. All the microtubules disappeared (fig. 4d). The oocytes were washed and transferred to estramustine phosphate-free medium and cultured for $2 \mathrm{~h}$. They were then fixed and the cryostat sections stained with antitubulin antibody. Microtubules reappeared in the oocyte (fig. 4f), as in control oocytes. The microtubules which were induced to depolymerize by estramustine phosphate were therefore capable of repolymerizing after the drug was removed.

\section{Effects of estramustine phosphate and taxol on in ovo microtubules}

Taxol has two effects on maturing oocytes immediately following GVBD : it causes a considerable increase in the bundling of microtubules around the chromosomes and induces the formation of asters in the cytoplasm (Rime et al., 1987). The whole region near the chromosomes was stained by anti-tubulin antibody (fig. 6a) 5051 and by JA2 antibodies, as in control oocytes (figs. 6b, c). The cytoplasmic asters were also decorated by the three antibodies. Using indirect double immunofluorescence staining under the light microscope, we could not discern whether JA2 and 5051 antibodies decorated the microtubules themselves or the perimicrotubular regions, although the anti-tubulin and 5051 antibody patterns were very similar (figs. 6a, b). The capacity of taxol (known to induce microtubule polymerization in vitro: Schiff et al., 1979 and in vivo: Heidemann and Gallas, 1980) to induce microtubule assembly in estramustine phosphate-treated oocytes was determined by incubating oocytes at the time of GVBD with $50 \mu \mathrm{M}$ of estramustine phosphate for $1 \mathrm{~h}$; taxol was then added and its effect analysed $15 \mathrm{~min}$ later. As shown in table 1 and figures $6 \mathrm{~d}$ and e, estramustine phosphate decreased the efficiency of the induction of cytoplasmic asters by taxol.

\section{TABLE I}

Effect of prior exposure to estramustine phosphate upon taxol-induced asters in denuded oocytes.

\begin{tabular}{cccc}
\hline & Taxol & Estramustine phosphate plus taxol \\
\hline $\begin{array}{c}\text { Number of oocytes } \\
\text { analyzed }\end{array}$ & $\begin{array}{c}\text { Number of cytasters } \\
\text { per oocyte } \\
\text { (mean } \pm \text { SD) }\end{array}$ & $\begin{array}{c}\text { Number of oocytes } \\
\text { analyzed }\end{array}$ & $\begin{array}{c}\text { Number of cytasters } \\
\text { per oocyte } \\
\text { (mean } \pm \text { SD) }\end{array}$ \\
\hline 14 & $3.42 \pm 1.4$ & 15 & $1.7 \pm 1.35^{\circ}$ \\
\hline
\end{tabular}

a : $P<0.01$ (t-test).

In both series of experiments, taxol $(10 \mu \mathrm{M}, 15 \mathrm{~min})$ was added after $4 \mathrm{hr}$ of culture. In estramustine phosphate-treated oocytes, the drug $(50 \mu \mathrm{M})$ was added $1 \mathrm{hr}$ before taxol treatment.

FIG. 5. - Immunofluorescence labelling of control and estramustine phosphate-treated metaphase /l oocytes with anti-tubulin, 5051 and JA2 antibodies. Control oocytes were stained at metaphase II by anti-tubulin (a) and 5051 (b) antibodies. Hoechst dye (c). Anti-tubulin (d) and 5051 (e) antibody and chromosome (f) patterns for sections of estramustine phosphate-treated metaphase II oocytes $(50 \mu \mathrm{M}, 15 \mathrm{~min})$.

$\mathrm{fm}=$ foci of microtubules; $\mathrm{pb}=$ polar body $; \mathrm{fc}=$ follicular cells ; $\mathrm{ch}=$ condensed chromosomes ; Bar $=10 \mu \mathrm{m}$. 


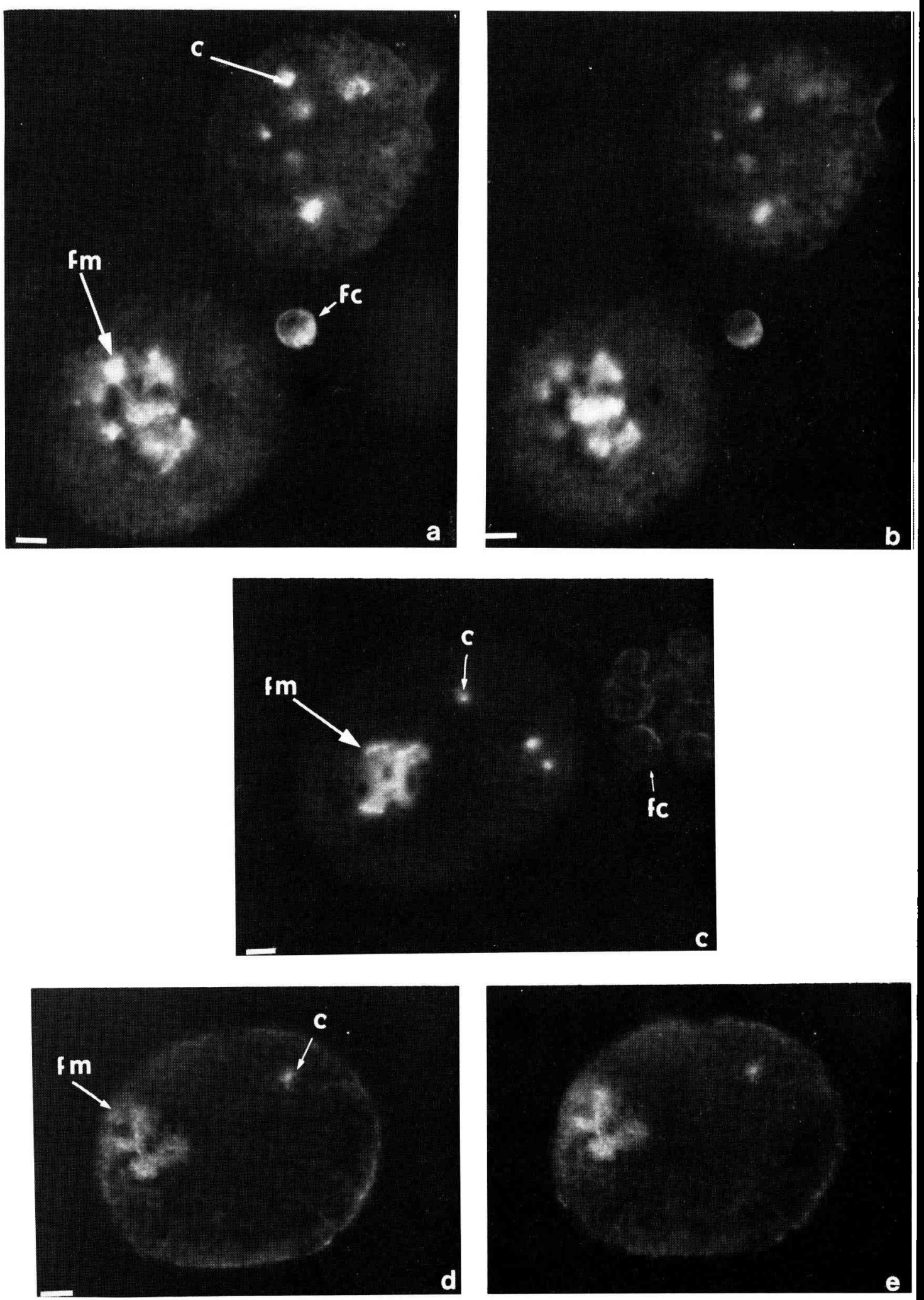




\section{Discussion.}

Estramustine phosphate $(50 \mu \mathrm{M})$, an estradiol mustard, was found to have two major effects on mouse oocytes: it inhibited the breakdown of the nuclear envelope and provoked the reversible depolymerization of metaphase microtubules. It also partially inhibited the induction of asters by taxol in maturing oocytes after GVBD.

The block of oocyte maturation by estramustine phosphate was reversible and very similar to the inhibition of the maturation of mouse and rabbit oocytes induced by isopropyl-N-phenylcarbamate (IPC), an antimitotic agent which particularly affects cells lacking centrioles (Crozet and Szöllösi, 1979). Estramustine consists of estradiol- $17 \beta$ linked to nitrogen mustard by a carbamate ester bond. It is therefore a plausible hypothesis that the carbamate moieties of both drugs act at the same level to inhibit GVBD. However, the effective inhibiting dose of IPC is higher $(200 \mu \mathrm{M})$ than that of estramustine phosphate $(50 \mu \mathrm{M})$ suggesting that the steroid moiety amplifies the effect of the estramustine molecule. To induce its action, the lipophilic steroid may control the targeting of the drug to a hydrophobic site, perhaps an intracellular membrane such as the nuclear envelope. Interestingly, it was recently shown that fluorescent dansylated estramusine accumulates in human prostatic tumor cells around the nuclear envelope (Stearns et al., 1985). However, the way in which these drugs interact with the nuclear envelope remains unknown. Van Blerkom and Bell (1986) reported that nocodazole, a drug which depolymerizes microtubules by binding to the molecule of tubulin (Hoebeke et al., 1976), does not inhibit GVBD in mouse oocyte but does inhibit spindle formation. We have successfully repeated this experiment. Thus, intact microtubules are not necessary for the breakdown of the nuclear envelope. In contrast, estramustine phosphate, which does not interact with the tubulin molecule itself but probably with microtubule-associated proteins (Kanje et al., 1985; Wallin et al., 1985), inhibits GVBD and also induces the depolymerization of oocyte microtubules. Therefore, estramustine may not inhibit GVBD by acting on the microtubules, but by other mechanism implicating the interaction of putative MAPs and nuclear envelope breakdown.

It is interesting to note that the metaphase spindle was stained by both the anti-tubulin and the 5051 antibody. This is in contrast to the observations of Calarco-Gillam et al. (1983), Maro et al. (1985) and Shatten et al. (1986) who, after carrying out indirect immunofluorescence of oocytes in toto, found that only the poles of the metaphase were stained by 5051 antibody. The non-metaphase

FIG. 6. - Effects of estramustine phosphate and taxol on the microtubules of the oocyte at GVBD. Sections of oocytes treated by $10 \mu \mathrm{M}$ taxol for 15 min at GVBD, and stained by anti-tubulin (a), 5051 (b) and JA2 (c) antibodies. Sections of oocytes treated by $50 \mu \mathrm{M}$ of estramustine phosphate for $1 \mathrm{hr}$, and then in estramustine phosphate plus taxol $(10 \mu \mathrm{M})$ for $15 \mathrm{~min}$ and stained by anti-tubulin (d) and 5051 (e) antibodies.

$\mathrm{fm}=$ foci of microtubules $; \mathrm{fc}=$ follicular cells $; \mathrm{c}=$ cytasters ; Bar $=10 \mu \mathrm{m}$. 
pericentriolar material foci described by Maro et al. (1985) and Shatten et al. (1986) were never observed in the present study. This discrepancy may be due to our immunofluorescence technique on cryostat sections that allows a better diffusion of the antibody, and then responsible for labelling of the antigen along the whole spindle. This unusual observation raises the question of whether the 5051 serum revealed an antigen which was not limited to the spindle poles but distributed throughout the metaphase spindle. Only an electron microscope immunofluorescence study can determine if this antigen is localized on the microtubules or in the cytoplasm around the microtubules. This particular distribution of the antigen, known to recognize the MTOCs of somatic cells, could be a particularity of the meiotic metaphase spindle which remains stable until sperm penetration.

A major question therefore is : is the in vivo inhibitory effect of estramustine phosphate on oocyte microtubules caused by interaction with MAPs? Although our results do not answer this question directly, they show that :

1) Estramustine induced the disappearance of the MTOCs, as revealed by 5051 antibody (figs. 3e, 4e, 5c), since no MTOCs can be observed after estramustine phosphate treatment of oocytes at different stages of maturation (GV, GVBD and metaphase).

2) Estramustine dissociates the co-localization (observed by immunofluorescence) of microtubules and antigens revealed by both the antiMAP1 and the 5051 antibodies after GVBD. Since estramustine phosphate did not bind to tubulin, the antigens recognized by the JA2 and 5051 antibodies may be the target for estramustine phosphate, in agreement with the hypothesis that the drug preferentially acts on MAPs (Kanje et al., 1985; Wallin et al., 1985).

As noted above, the antigens recognized by JA2 and 5051 antibodies remain unknown. Although non-tubulin protein antigens recognized by both the 5051 and the JA2 antibodies are associated with microtubules after GVBD, their cellular distribution is strikingly different in prophase-maintained oocytes (figs. $3 \mathrm{~b}, \mathrm{c}$ ). In these oocytes the nuclear localization of MAP1-cinalog antigen was unchanged by estramustine phosphate treatment (fig. 3f). Since MAP1-analog became associated with the microtubules after GVBD, it could be involved, as already suggested, in the genesis of new MTOCs when the nuclear envelope breaks down (Sato et al., 1983 ; Bloom et al., 1984 ; Bonifacino et al., 1985 ; Ohno et al., 1985 ; Jessus et al., 1986 ; Sato et al., 1986).

The observation that estramustine phosphate decreased the in vivo bundling action of taxol may be significant, suggesting that estramustine phosphate counteracts the in vivo taxol effect in mouse oocyte. In an earlier study (Rime et al., 1987), we showed that JA2 antibody decorated asters induced by taxol in maturing oocytes, indicating that non-tubulin proteins might participate in the production of taxol-induced asters. A specific MAP, which remains to be identified, may thus be involved in the formation of asters after taxol treatment. 
Acknowledgements. - The anti-MAP1 antibody (JA2) was the kind gift of Dr Marc De Brabander (Janssen Pharmaceutica Research Laboratories, Beerse, Belgium). The antiMTOC antibody (5051) was kingly provided by Dr Calarco-Gillam (University of California, San Francisco, USA). The estramustine phosphate was the gift of Dr Hartley-Asp (AB Leo, Research Laboratories, Helsingborg, Sweden) and taxol was contributed by Dr M. Suffness (National Institute of Health, Bethesda, MD, USA). This research was supported by MRT, CNRS, INRA and INSERM.

Résumé. Le phosphate d'estramustine inhibe la rupture de l'enveloppe nucléaire et induit la dépolymérisation des microtubules de l'ovocyte de souris.

L'ovocyte de Souris bloqué en prophase de première division méiotique (maturation méïotique), libéré de son follicule, reprend spontanément sa méïose in vitro. Ce travail montre que le phosphate d'estramustine bloque de manière réversible la maturation méïotique en inhibant la rupture de l'enveloppe nucléaire. Les coupes à congélation d'ovocytes de Souris sont marquées par l'anticorps anti-tubuline et par deux anticorps qui décorent le fuseau de métaphase (anti-MAP1 : JA2 et le sérum 5051) pendant la maturation méiotique. II a été montré que : (1) le phosphate d'estramustine dépolyn iérise les microtubules in ovo et disperse les antigènes associés aux microtubules du fuseau de métaphase à différentes étapes de la maturation. (2) le phosphate d'estramustine diminue la capacité du taxol à induire des asters cytoplasmiques. Ces résultats suggèrent que les protéines associées aux microtubules soient impliquées dans la rupture de l'enveloppe nucléaire.

\section{References}

BLOOM G. S., LUCA F. C., VALLEE R. B., 1984. Widespread cellular distribution of MAP-1A (microtubule-associated protein $1 A$ ) in the mitotic spindle and on interphase microtubules. $J$. Cell Biol., 98, 331-340.

BONIFACINO J. S., KLAUSNER R., SANDOVAL I. V., 1985. A widely distributed nuclear protein immunologically related to the microtubule-associated protein MAP1 is associated with the mitotic spindle. Proc. nat. Acad. Sci. USA., 82, 1146-1150.

BRINKLEY B. R., 1985. Microtubule organizing centers. Annu. Rev. cell. Biol., 1, 145-172.

CALARCO P. D., DONAHUE R. P., SZÖLLÖSI D., 1972. Germinal vesicle breakdown in mouse oocyte. J. Cell Sci, 10, 369-385.

CALARCO-GILLAM P. D., SIEBERT M. C., HUBble R., MITCHISON T., KIRSCHNER M., 1983. Centrosome development in early mouse embryos as defined by an autoantibody against pericentriolar material. Cell, 35, 621-629.

CROZET N., SZÖLLÖSI D., 1979. The effects of isopropyl-N-phenyl carbamate on meiotic maturation of mammalian oocytes. Ann. Biol. anim. Bioch. Biophys., 19, 1131-1140.

DAGENAIS A., BIBOR-HARDY V., SIMARD R., 1984. Characterization of lamin proteins in BHK cells. Exp. Cell Res., 155, 434-447.

DE BRABANDER M., DE MEY J., GEUENS G., NUYDENS R., AERTS F., WILLEBRORDS R., MOEREMANS M., 1985. Microtubules in cell organization and motility. In DUMONT S. E., HAMPRECHT B., NUNEZ J., Hormones and cell regulation, vol. 9, eds), Elsevier biomed. Press, Amsterdam, pp. 85-104.

DE MEY J., AERTS F., MOEREMANS M., GEUENS G., DANEELS G., DE BRABANDER M., 1984. Anti-MAP1 reacts with the centrosomes, kinetokores, midbody and spindle of mitotic PTK2 cells. J. Cell Biol., 99, 447a.

DONAHUE R. P., 1968. Maturation of mouse oocyte in vitro. 1. Sequence and timing of nuclear progression. J. exp. Zool., 169, 237-250.

FULTON B. P., WHITTINGHAM D. G., 1978. Activation of mammalian oocytes by intracellular injection of calcium. Nature, 273, 149-151.

GERACE L., COMEAU C., BENSON M., 1984. Organization and modulation of nuclear lamina structure. J. Cell Sci., 1, 137-160. 
HARTLEY-ASP B., 1984. Estramustine-induced mitotic arrest in two human prostatic carcinoma cell lines Du 145 and Pc-3. The Prostate, 5, 93-100.

HARTLEY-ASP B., GUNNARSSON P. O., 1982. Growth and cell survival following treatment with estramustine nor-nitrogen mustard, estradiol and testosterone of human prostatic cancer cell line. J. Urol.r, 82, 818-822.

HEIDEMANN S. R., GALLAS P. T., 1980. The effect of taxol on living eggs of Xenopus laevis. Dev. Biol., 80, 489-494.

HOEBEKE J., VAN NIJEN G., DE BRABANDER M., 1976. Interaction of nocodazole (R17934), a new anti-tumoral drug, with rat brain tubulin. Biochem. biophys. Res. Commun., 69, 319324.

IZANT J. G., WETHERBEE J. A., Mc INTOSH J. R., 1982. A microtubule-associated protein in the mitotic spindle and the interphase nucleus. Nature, 295, 248-250.

JESSUS C., HUCHON D., OZON R., 1986. Distribution of microtubules during breakdown of the nuclear envelope of the Xenopus oocyte : an immunocytochemical study. Biol. Cell, 56, 113120.

KANJE M., DEINUM J., WALLIN M., EKSTRÖM P., EDSTRÖM A., HARTLEY-ASP B., 1985. Effect of estramustine phosphate on the assembly of isolated bovine brain microtubule and fast axonal transport in the frog sciatic nerve. Cancer Res., 45, 2234-2239.

MARO B., HOWLETT S. K., WEBB M., 1985. Non-spindle microtubule organizing centers in Metaphase II-arrested mouse oocytes. J. Cell Biol., 101, 1665-1672.

OHNO T., OHKAWA A., SATO C., 1985. Factors controlling the appearance of the immunofluorescent nuclear dots revealed with monoclonal antibody against microtubule-associated protein 1. Exp. Cell Res., 158, 558-562.

RIME H., JESSUS C., OZON R., 1987. Distribution of microtubules during the first meiotic cell division in the mouse oocyte : effect of taxol. Gamete Res., 17, 1-13.

SATO C., NISHIZAWA K., NAKAMURA H., KOMAGOE Y., SHIMADA K., UEDA R., SUZUKI S., 1983. Monoclonal antibody against microtubule-associated protein-1 produces immunofluorescent spots in the nucleus and centrosome of cultured mammalian cells. Cell Struct. Funct., 8, 245-254.

SATO C., NISHIZAWA K., NAKAYAMA T., NOSE K., TAKASAKI Y., HIROSE S., NAKAMURA H., 1986. Intranuclear appearance of the phosporylated form of cytoskeleton-associated 350kDa proteins in UI-ribonucleoprotein regions after growth stimulation of fibroblasts. Proc. nat. Acad. Sci. USA, 83, 7387-7291.

SCHATTEN H., SCHATTEN G., MAZIA D., BALCZON R., SIMERLY C., 1986 . Behavior of centrosomes during fertilization and cell division in mouse oocyte and sea urchin eggs. Proc. nat. Acad. Sci. USA, 83, 105-109.

SCHIFF P. B., FANT J., HORWITZ S. B., 1979. Promotion of microtubule assembly in vitro by taxol. Nature, 277, 665-667.

SHELANSK! M. L., GASKIN F., CANTOR C. R., 1973. Microtubule assembly in the absence of added nucleotides. Proc. nat. Acad. Sci. USA, 70, 765-768.

STEARNS M., JENKINS D. P., TEW K. D., 1985. Dansylated estramustine, a fluorescent probe for studies of estramustine uptake and identification of intracellular targets. Proc. nat. Acad. Sci. USA, 82, 8483-8487.

STEARNS M. E., TEW K. D., 1985. Antimicrotubule effects of estramustine, an antiprostatic tumor drug. Cancer Res., 45, 3891-3897.

SZOLLÖSI D., CALARCO P., DONAHUE R. P., 1972a. The nuclear envelope : its breakdown and fate in mammalian oogonia and oocytes. Anat. Rec., 174, 325-340.

SZÖLLÖSI D., CALARCO P., DONAHUE R. P., 1972b. Absence of centrioles in the first and second meiotic spindles of mouse oocytes. J. Cell Sci, 11, 521-541.

VAN BLERKOM K., BELL H., 1986. Regulation of development in the fully grown mouse oocyte : chromosome-mediated temporal and spatial differentiation of the cytoplasm and plasma membrane. J. Embryol. exp. Morph., 93, 213-238.

WALLIN M., DEINUM J., FRIDÉN B., 1985. Interaction of estramustine phosphate with microtubuleassociated proteins. FEBS Lett., 179, 289-293.

WICHE G., BRIONES E., KOSZKA C., ARTLIEB U., KREPLER R., 1984. Widespread occurrence of polypeptides related to neurotubule-associated proteins (MAP-1 and MAP-2) in non-neuronal cells and tissus. EMBO J., 3, 991-998. 